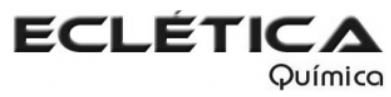

www.scielo.br/eq

www.ecletica.iq.unesp.br

Volume 33, número 3, 2008

\title{
Thermal behavior of corn starch granules modified by acid treatment at 30 and $50^{\circ} \mathrm{C}$
}

\author{
C. Benincal, I. M. Demiate ${ }^{1}$, L. G. Lacerda ${ }^{2}$, M. A. S. Carvalho Filho ${ }^{3}$, M. Ionashiro and E. Schnitzler $^{*}$ \\ ${ }^{\prime}$ Universidade Estadual de Ponta Grossa - UEPG. Av. Carlos Cavalcanti, 4748. CEP 84030-000 - Ponta Grossa - PR, Brazil. \\ ${ }^{2}$ Universidade Federal do Paraná - UFPR. Curitiba - PR. Brazil \\ ${ }^{3}$ Universidade Positivo - UNICENP. Curitiba - PR. Brazil \\ ${ }^{4}$ Universidade Estadual Paulista - UNESP. Araraquara - SP - Brazil \\ "egons@uepg.br
}

\begin{abstract}
Unprocessed native starches are structurally too weak and functionally too restricted for application in today's advanced food technologies. Processing is necessary to engender a range of functionality. Naturals or natives starches can be modified by using several methods physical, chemical, enzymatic or combined, according industrial purposes. In this work, native corn starch was hydrolyzed by hydrochloric acid solution and investigated by using thermoanalytical techniques (thermogravimetry - TG, differential thermal analysis - DTA and differential scanning calorimetry - DSC), as well as optical microscopy and X-ray diffractometry. After acid treatment at 30 and $50^{\circ} \mathrm{C}$, a decrease of gelatinization enthalpy $\left(\Delta \mathrm{H}_{\mathrm{gel}}\right)$ was verified. Optical microscopy and X-ray diffractometry allowed us to verify the granules contorn and rugosity typical of cereal starches.
\end{abstract}

Keywords: Corn starch; TG; DTA; DSC; gelatinization.

\section{Introduction}

Starch is a raw material of different botanical origins, and the most important storage reserve carbohydrate in plants. It is used by the food, paper, chemical, pharmaceutical and textile industries, among many others. More than $80 \%$ of the world starch market originates from corn [1]. Corn starch is a valuable ingredient to the food industry, being widely used as a thickener, gelling agent, bulking agent and water retention agent [2].

Starch, a semi-crystalline polymer, is composed of two polysaccharides: amylose and amylopectin. Amylose, a mostly linear chain, typically consists up to 3000 glucose molecules interconnected primarily by $\alpha-1,4$ glycosidic linkages and is reported to contain a few branched networks [3].
Amylopectin is a large branched polymer with linkages of $\alpha-1,4$ that serve as the backbone and $\alpha-1,6$ bridges at the branching points [4]. When starch is heated in the presence of enough water, its crystalline organization decomposes to form amorphous regions [5]. This molecular disordering is called gelatinization and is frequently observed as endothermic phenomenon using differential scanning calorimetry (DSC) [6]. Thermogravimetry (TG) can be helpful to show the behaviour of starch granules when heating leads to depolymerization [7].

Hydrolytic starch transformations are made by several methods such as chemical, thermal and by enzymatic processes. Acid modification has been applied to improve the physicochemical properties of starch, particularly in food industry, were they are used in gum candies. Acid modification 
allows the starch to be used at a higher solids concentration for quick gelling and it provides gum or jelly with shorter texture and flexible properties. It has also been used extensively in textile and paper industries. In acid modification, the hydroxonium ion attacks the glycosidic oxygen atom and hydrolyses the glycosidic linkage. Acid modification changes the physicochemical properties of starch without destroying its granule structure [8].

\section{Experimental}

\section{Samples}

Commercial grade granular corn starch (Maizena ${ }^{\circledR}$ ) Unilever Bestfoods, Mogi Guaçu, SP, Brazil was acquired in the local trade. Other chemicals used in this study were analytical reagent grade. Modified starch by acid treatment was produced in the laboratory by following the procedure described at literature [8]. One hundred grams of native starch were added to 500 $\mathrm{mL}$ of hydrochloric acid solution $0.15 \mathrm{~mol} \mathrm{~L}^{-1}$ and maintained under continuous stirring by 8 hours at $30^{\circ} \mathrm{C}$. The same procedure was followed while the temperature maintained at $50^{\circ} \mathrm{C}$. After this time, each solution was filtered and washed with distilled water until complete elimination of chloride ions, dried at room temperature $\left(20^{\circ} \mathrm{C}\right)$ and kept in a desiccator over anhydrous calcium chloride until constant mass.

\section{Methods}

TG and DTA curves were recorded using a simultaneous TG 60 system (Shimadzu) under an air flow at $100 \mathrm{~mL} \mathrm{~min}-1$ and at a heating rate of $10^{\circ} \mathrm{C}$ min $^{-1}$. The initial sample mass was about 9 $\mathrm{mg}$. Alumina crucibles were used for the TG and DTA experiments. DSC curves were recorded using a DSC 60 (Shimadzu) under an air flow at $100 \mathrm{~mL}$ $\mathrm{min}^{-1}$, heating rate of $5^{\circ} \mathrm{C} \mathrm{min}-1$. A 4:1 (water:starch $\mathrm{w} / \mathrm{w}$ ) mixture was prepared and left for two hours in order to equilibrate the moisture content. Sealed aluminum crucibles were used and the studies were carried out in order to study the gelatinization.

Microscopy analysis was carried out using an SZX 9 stereo microscope (Olympus), with polarization filter and Cybernetic's Cool Snap Pro color camera. The photographs were identified and scaled using Image Pro Plus with $\mathrm{N}=1000 \mathrm{X}$ magnification.

$\mathrm{X}$ Ray diffraction powder patterns were obtained by using a D-5000 X Ray diffractometer (Siemens), with $\mathrm{CuK} \alpha$ radiation $(\lambda=1.544$ $\AA$ ) and a setting of $40 \mathrm{kV}$ and $20 \mathrm{~mA}$.

\section{Results and discussion}

According to Aggarwal and Dollimore [9], thermal treatment of starches normally leads to their degradation when the applied temperature exceeds
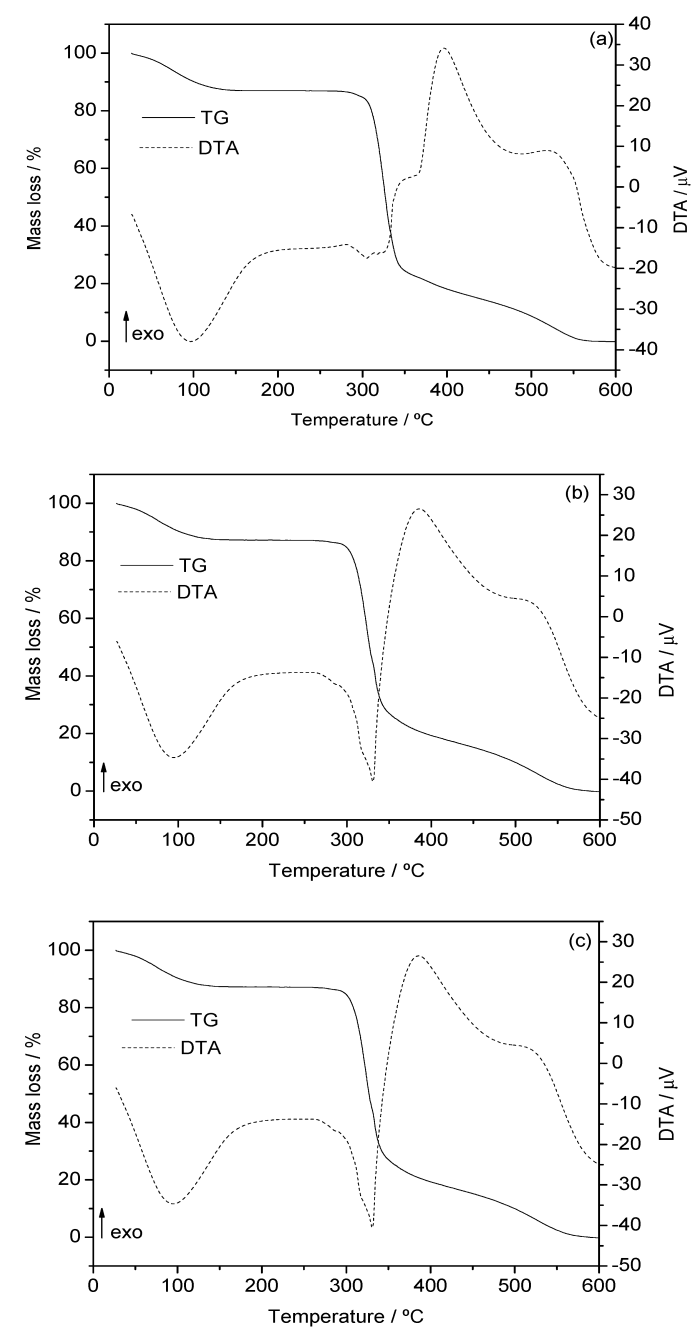

Figure 1. TG and DTA curves of corn starch granules: (a) untreated, $9.13 \mathrm{mg}$; (b) acid modified at $30^{\circ} \mathrm{C}, 9.07 \mathrm{mg}$; (c) acid modified at $50^{\circ} \mathrm{C}, 8,41 \mathrm{mg}$. 
$300^{\circ} \mathrm{C}$. The second major breakdown process does not occur under inert atmosphere and is therefore considered to be the oxidation of the partially decomposed organic material [10].

Simultaneous TG-DTA curves of corn starch granules untreated and treated with acid at $30^{\circ} \mathrm{C}$ or $50^{\circ} \mathrm{C}$ are shown in Figure 1.

These curves show mass losses in three steps and thermal events corresponding to these losses. A great similarity is observed in the TGDTA profiles, both for corn starch granules untreated and treated with acid at $30^{\circ} \mathrm{C}$ or $50^{\circ} \mathrm{C}$. In all the TG-DTA curves, the first mass loss that occurs between 30 and $116^{\circ} \mathrm{C}$, corresponding to endothermic peaks at 96,95 and $93^{\circ} \mathrm{C}$, respectively is attributed to the dehydration, that occurs in a single step.

Once dehydrated, the compounds are stable up to 305,295 and $293^{\circ} \mathrm{C}$, and above these temperatures the thermal decomposition of amylose and amylopectin occurs in two consecutives steps up to 553,554 and $570^{\circ} \mathrm{C}$, corresponding to endothermic and exothermic peaks, respectively. These curves also show that the first mass loss occurs through a fast process, followed by a slow process for the second one, and significant difference in the DTA profiles between the corn starch untreated and treated with hydrochloric acid solution. In all the TG curves the final residue was smaller than $0.1 \%$.

The temperature ranges $\theta$, mass losses and peak temperatures observed for each step of the TG-DTA curves of the samples, are shown in Table 1. DSC curves of the samples are shown at Figure 2. The instrument was calibrated with indium, and an empty pan was used as reference. The characteristics of the transitions, including onset temperature $\left(\mathrm{T}_{\mathrm{o}}\right)$, peak temperature $\left(\mathrm{T}_{\mathrm{p}}\right)$ and enthalpy of gelatinization $(\Delta \mathrm{H})$ were calculated.

The energy required for the molecular order disrupture differs with the realized treatment, being

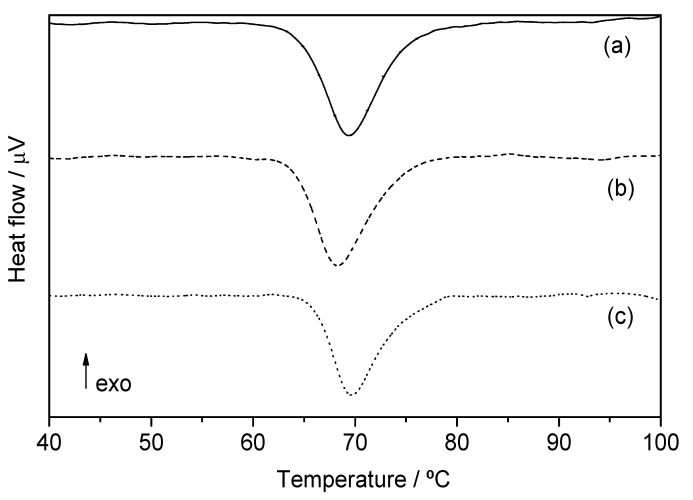

Figure 2. DSC curves of corn starch granules: (a) untreated; (b) acid modified at $30^{\circ} \mathrm{C}$; (c) acid modified at $50^{\circ} \mathrm{C}$.

larger for untreated corn starch $\left(\Delta \mathrm{H}=19.92 \mathrm{~J} \mathrm{~g}^{-1}\right)$, followed by acid modified starch at $30^{\circ} \mathrm{C}(\Delta \mathrm{H}=$ $\left.15.99 \mathrm{~J} \mathrm{~g}^{-1}\right)$ and by acid modified starch at $50{ }^{\circ} \mathrm{C}$ $\left(\Delta \mathrm{H}=13.41 \mathrm{~J} \mathrm{~g}^{-1}\right)$. Onset and peak temperatures of each sample are shown in Table 2.

Native starch granules of corn observed in Figure 3 (a) shows differences in their shape and size. Corn presented irregular polyhedral morphology, with diameters between 5 and $20 \mu \mathrm{m}$ approximately, confirming what was previously reported in $[11,12,13]$. During the acid treatment the granules gradually underwent morphologic alterations as it can be observed in Figures 3 (b) and (c).

Table 2. Onset temperature $\left(\mathrm{T}_{\mathrm{o}}\right)$, peak temperature $\left(\mathrm{T}_{\mathrm{p}}\right)$ and gelatinization enthalpy $\left(\Delta \mathrm{H}_{\mathrm{gel}}\right)$ obtained by DSC: (a) untreated; (b) acid modified at $30^{\circ} \mathrm{C}$; (c) acid modified at $50^{\circ} \mathrm{C}$.

\begin{tabular}{lccc}
\hline Sample & $\mathrm{T}_{0}\left({ }^{\circ} \mathrm{C}\right)$ & $\mathrm{T}_{\mathrm{p}}\left({ }^{\circ} \mathrm{C}\right)$ & $\mathrm{DH}_{\text {gel }}(\mathrm{J} / \mathrm{g})$ \\
\hline Untreated starch (a) & 66,33 & 72,44 & 19,92 \\
Acid modifies at $30^{\circ} \mathrm{C}(\mathrm{b})$ & 63,55 & 68,07 & 15,99 \\
Acid modified at $50^{\circ} \mathrm{C}$ (c) & 65,23 & 69,60 & 13,41 \\
\hline
\end{tabular}

Table 1. Temperature ranges, mass losses and peak temperatures observed for each step of the TG-DTA curves of the samples.

\begin{tabular}{|c|c|c|c|c|c|c|c|c|c|}
\hline \multirow[b]{2}{*}{ Sample } & \multicolumn{3}{|c|}{ Dehydration } & \multicolumn{6}{|c|}{ Decompositions } \\
\hline & $\Delta \mathrm{T}_{1}\left({ }^{\circ} \mathrm{C}\right)$ & $\Delta \mathrm{m}_{1}(\%)$ & peak $\left({ }^{\circ} \mathrm{C}\right)$ & $\Delta \mathrm{T}_{2}\left({ }^{\circ} \mathrm{C}\right)$ & $\Delta \mathrm{m}_{2}(\%)$ & Peak $\left({ }^{\circ} \mathrm{C}\right)$ & $\Delta \mathrm{T}_{3}\left({ }^{\circ} \mathrm{C}\right)$ & $\Delta \mathrm{m}_{3}(\%)$ & Peak $\left({ }^{\circ} \mathrm{C}\right)$ \\
\hline Untreated starch (a) & $30-116$ & 12,8 & 96 & $305-342$ & 63,8 & 310,330 & $342-553$ & 23,3 & 400 \\
\hline Acid modified at $30^{\circ} \mathrm{C}($ b) & $30-115$ & 13,5 & 95 & $295-341$ & 63,0 & 330 & $341-564$ & 23,4 & 390 \\
\hline Acid modified at $50^{\circ} \mathrm{C}$ (c) & $30-115$ & 12,7 & 93 & $293-344$ & 62,0 & 330 & $344-570$ & 25,3 & 390 \\
\hline
\end{tabular}




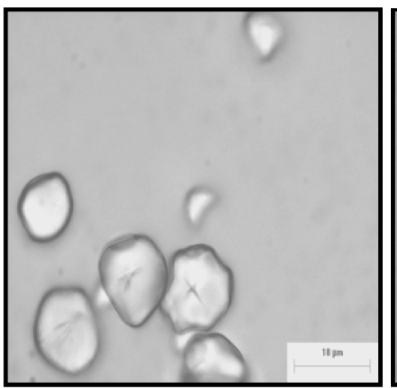

(a)

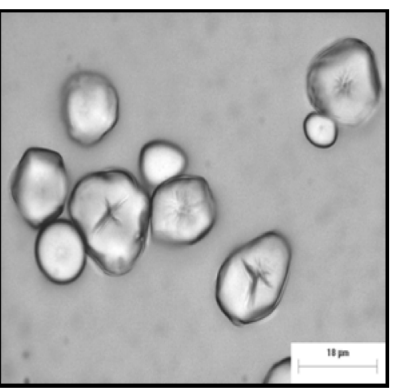

(b)

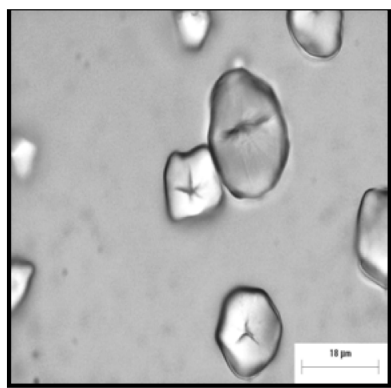

(c)

Figure 3. Photomicrograph of: (a) untreated corn starch granules; (b) treated with $\mathrm{HCl}$ $0.15 \mathrm{~mol} \mathrm{~L}{ }^{-1}$ at $30^{\circ} \mathrm{C}$; (c) treated with $\mathrm{HCl} 0.15 \mathrm{~mol} \mathrm{~L}^{-1}$ at $50^{\circ} \mathrm{C}$. (magnification $1000 \mathrm{X}$ ).

Starches tend to present pertinent crystalline arrangements depending on their botanical origin [11]. According to Cereda and Vilpoux [12], the intensity of few diffraction peaks can suggest different crystallinity patterns. For corn starch (type A pattern), these peaks appear predominantly as one doublet at $2 \theta=18^{\circ}$ and only a peak occurring at $2 \theta=23^{\circ}$ as can be seen in Figure 4(a) and (b). When the sample was treated with $\mathrm{HCl}$ $0.15 \mathrm{~mol} \mathrm{~L}^{-1}$ at $50^{\circ} \mathrm{C}$ - Figure $4(\mathrm{c})$, the peak at $2 \theta$ $=18^{\circ}$ is not observed. Probably it can be explained

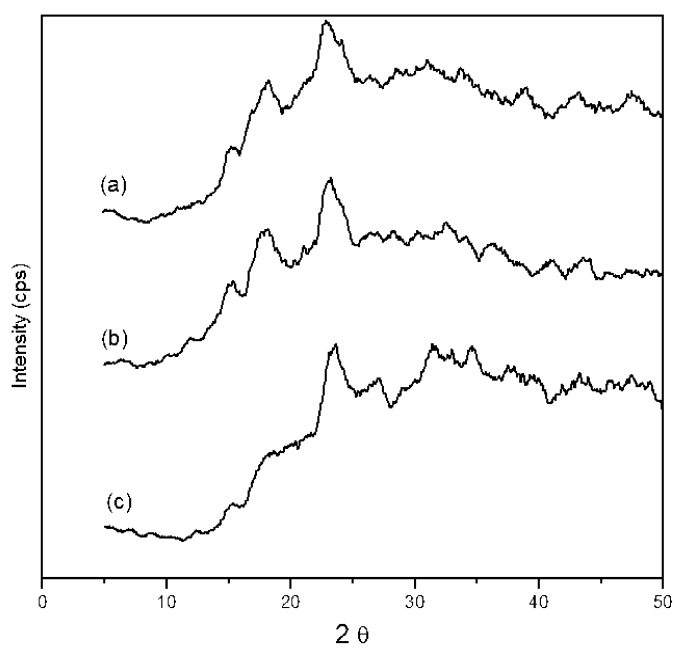

Figure 4. X-ray diffraction powder patterns of the compounds: (a) untreated corn starch granules; (b) treated with $\mathrm{HCl} 0.15 \mathrm{~mol} \mathrm{~L}^{-1}$ at $30^{\circ} \mathrm{C}$; (c) treated with $\mathrm{HCl} 0.15 \mathrm{~mol} \mathrm{~L}^{-1}$ at $50^{\circ} \mathrm{C}$. that upon hydrolysis, crystallinity alterations were observed, once $\alpha$-amylase acts mainly in the amorphous region the granules $[6,11,12]$.

\section{Conclusions}

In spite of the similarity between the TG curves, significant difference is observed in the DTA profiles of the corn starch untreated and treated with hydrochloric acid solution.

DSC curves permitted to determine the gelatinization enthalpy, which decreases according with the temperature employed.

Optical microscopy confirms morphological characteristics of cereal starch granules, and the acid treatment acts initially on its surface, especially in imperfections.

$\mathrm{X}$-ray diffraction confirmed the characteristic of native pattern and the increase of intensity of main peaks suggesting that the crystalline part was not influenced by acid treatment or temperature.

\section{Acknowledgements}

Authors thanks for CAPES for financial support and for Universidade Positivo.

Received June 042008

Accepted July 212008 
C. Beninca, I. M. Demiate, L. G. Lacerda, M. A. S. Carvalho Filho, M. Ionashiro and E. Schnitzler. Comportamento térmico de grânulos de amido de milho modificados por tratamento ácido a 30 e a $50^{\circ} \mathrm{C}$.

Resumo: Os amidos nativos são estruturalmente fracos e pouco resistentes para aplicações tecnológicas na indústria alimentícia. O processamento é necessário para conferir aos amidos maior aplicabilidade. Os amidos nativos podem ser modificados por vários processos como: físicos, químicos, enzimáticos ou até combinações dos mesmos, dependendo da finalidade industrial. Amostras de amido de milho nativo foram submetidas à hidrólise por solução de ácido clorídrico e investigadas através das técnicas termoanalíticas: termogravimetria (TG), análise térmica diferencial (DTA) e calorimetria exploratória diferencial (DSC), bem como microscopia óptica e difratometria de raios X pelo método do pó. Após tratamento com ácido clorídrico a 30 e a $50{ }^{\circ} \mathrm{C}$, foi verificado um decréscimo na entalpia de gelatinização $\left(\Delta \mathrm{H}_{\mathrm{gel}}\right)$. A microscopia óptica e difratometria de raios $\mathrm{X}$ permitiram verificar os contornos de grão e rugosidade típica dos amidos de cereais.

Palavras-Chave: amido de milho; TG; DTA; DSC; gelatinização.

\section{References}

[1] S. Jobling, Plant Biotech, 7, (2004), 210.

[2] N. Singh, J. Singh, L. Kaur, N.S. Sodhi and B. S. Gill, Food Chem, 81, (2003), 219.

[3] Y. Takeda, S. Tomooka and S. Hizukuri, Carbohydr. Res, 246, (1993), 267.

[4] H. Zobel, Starch/Stärke, 40, (1988), 44.

[5] W. A. Atwell, L. F. Hood, D. R. Lineback, E. VarrianoMarston and H. F. Zobel, Cereal Food Worlds, 33, (1988), 306.

[6] C. G. Biliaderis. Canadian J. Physiol. Pharmacol, 69, (1991), 60.

[7] E. Rudnik, G. Matuschek, N. Milanov and A. Kettrup, J. Therm. Anal. Cal, 85, (2006), 267.
[8] O. S. Lawal, K. O. Adebowale, B. M. Ogunsanwo, L. L. Barba and N. S. Ilo, Int. J. Biol. Macromol, 35, (2005), 71.

[9] P. Aggarwal and D. Dollimore. Thermochim. Acta, 319, (1998), 17.

[10] P. Aggarwal, D. Dollimore and K. Heon, J. Therm. Anal, 50, (1997), 7.

[11] G. Zhang, Z. Ao and B. R. Hamaker. Biomacromol. 7, (2006), 3252

[12] M. P. Cereda and O Vilpoux. Tecnologia, Usos e Potencialidades de tuberosas amiláceas Latino Americanas, Fund. Cargill, São Paulo, 2003.

[13] C. G. Mothé, D. Z. Correia, F. P de França and A. T. Riga,

J. Therm. Anal. Cal. 85, (2006), 31. 
EQ02-AF $\quad 21 / 8 / 14 \quad 5: 51 \quad$ Page 18 